\title{
Initiatives for the improvement of continuous management training
}

\section{Iniciativas para la mejora de la formación continua directiva}

\author{
JON LANDETA ${ }^{1}$ \\ JON BARRUTIA ${ }^{1}$ \\ JON HOYOS $^{1}$ \\ Andrés Araujo ${ }^{1}$ \\ University of the Basque Country - UPV/EHU (Spain)
}

Recibido el 17 de abril de 2013, aceptado el 3 de septiembre de 2014

$\mathrm{N}^{\mathrm{o}}$ de clasificación JEL: M53

DOI: $10.5295 / \mathrm{cdg} .130411 \mathrm{jl}$

\begin{abstract}
:
Purpose. This work aims to present, from the company viewpoint, a structured account of management proposals and practices directed toward improving the intensity and effectiveness of continuous management training $(C M T)$.

Design/methodology/approach. The article takes as its main theoretical referents the Theory of Human Capital, the Resource-Based Vision and the contributions made via the new institutional economy with regard to the problems of information asymmetry between companies, employees and training providers and completes the proposals that derive from this theoretical approach. To do this, experience-based contributions are collected from a selection of company training and HR managers from twelve Basque companies characterised by their strong investment in management training. The methodology used was qualitative and obtained by different qualitative techniques: Focus Groups, Nominal Groups and the Delphi Method, which make up the so-called Hybrid Delphi.
\end{abstract}

Findings and implications. The proposals are aimed at the main agents in training activity: training providers, associations and public agents engaged in management training and, particularly, companies themselves. The initiatives seek above all to increase training market transparency, to improve mutual commitments between companies and managers, and to link training and development with culture and strategic management, so that firms make optimal investment in management training.

Originality/value. The methodology used is original, and the contributions are consistent with the theory, have a proven practical utility, and are presented in a hierarchy, which facilitates decision making.

${ }^{1}$ Facultad de Ciencias Económicas y Empresariales, Dpto. Economía Financiera II, Avda. Lehendakari Aguirre, 83,48015, Bilbao (Bizkaia).jon.landeta@ehu.es; jon.barrutia@ehu.es; jon.hoyos@ehu.es; andres.araujo@ehu.es 


\section{Keywords:}

Managers, training, adverse selection, moral hazard, Delphi, information asymmetry.

\section{Resumen:}

Objetivo. La finalidad de este trabajo es presentar, desde el punto de vista de la empresa, un conjunto estructurado de propuestas y prácticas directivas orientadas a mejorar la intensidad y eficacia de la formación continua directiva

Metodología. El artículo toma como principales referentes teóricos la Teoría del Capital Humano, la Visión basada en los Recursos y las contribuciones procedentes de la Nueva Economía Institucional en relación con los problemas de asimetrías de información entre empresas, empleados y oferentes de formación. Las propuestas derivadas de esta aproximación teórica han sido completadas con contribuciones basadas en la experiencia aportada por una selección de directores de recursos humanos y de formación de doce empresas vascas destacadas por su fuerte inversión en formación directiva, obtenidas mediante diferentes técnicas cualitativas: Focus Groups, Nominal Groups y Método Delphi, que juntas conforman el denominado Hybrid Delphi.

Resultados e implicaciones. Las propuestas son dirigidas a los principales agentes de la actividad formativa: proveedores de formación directiva, asociaciones y agentes públicos implicados en la formación directiva y, especialmente, a las propias empresas. Las iniciativas apuestan sobre todo por incrementar la transparencia del mercado de la formación, por incrementar los compromisos mutuos entre empresa y directivos, y por relacionar formación y desarrollo directivo con cultura y dirección estratégica, de forma que las empresas puedan llegar a hacer la inversión óptima en formación continua directiva.

Originalidad/valor. La metodología empleada es original y las contribuciones son consistentes con la teoría, son de probada utilidad práctica y son presentadas en una jerarquía, lo que facilita la toma de decisiones.

\section{Palabras clave:}

Directivos, formación, selección adversa, riesgo moral, Delphi, asimetría de información . 


\section{INTRODUCTION}

Companies, managers and society itself are aware of the importance of training for the effective and efficient development of managerial activity. A clear demonstration of this commitment is the increasing extent of pre-work training possessed by managers (Araujo et al., 2001 y 2003), which is, moreover, most evident and to a growing degree in areas directly directed with business management. Companies and managers generally accept the positive existing relation between managers' skill levels and their contribution to company success and are aware of the need for continuous management training, or CMT (Russell, 1985; Ng et al. 2004; Garcia, 2007), as a means of development and permanent training, especially within the framework of a highly dynamic competitive environment (Pickett, 1998; Castanias and Helfat, 1991 and 2001; Adell et al., 2002; Landeta et al., 2007). The benefits of training programmes, in terms of business results (or at least the positive correlation between training effort and economic outcomes), have been pointed to in numerous studies (Aragón et al., 2003; Úbeda, 2005; Tharenou et al., 2007; Hansson, 2007; Nikandrou et al., 2008; Muñoz and Salinero, 2011; Ng and Dastmalchian, 2011), even in the specific case of management training (Marshall et al, 1995; Storey, 2004). The cost of management training, meanwhile, does not appear to be a determinant variable that would justify not providing educational backup in this area (Landeta et al., 2007). However, sharp differences are observed in the average level of CMT investment among countries, between managers with different levels and backgrounds in pre-work training, between managers of different ages, and between companies that even share management personnel and similar sectoral and geographical environments (Cedefop, 2004 and 2009).

The main reason for this uneven behaviour does not, therefore, seem to be that companies in different countries have diametrically opposed opinions about training, or to be due to the different economic possibilities available to companies, but lies rather in other factors, some of which may, in our view, be associated to some degree with information and knowledge.

That is to say, expectations of generating and appropriating worthwhile business results through management training condition the degree to which companies invest in this area. However, the level and nature of the information a firm possesses regarding this kind of training is of relevance to the shape these expectations take. Fundamentally we are talking about information on the potentiality of different training options (direct contact, general, specific...); on providers and offers available in the market; and concerning concrete individuals who might be the recipients of training activity (interest, need and learning capability of company managers and trainee managers, and their post-training behaviour).

The third Continuous Vocational Training Survey (CVTS3) organised by the European Union (Eurostat, 2007) also points in this direction. A two of the reasons put forward by companies that did not finance continuous training activities for their human capital in 2005, (apart from the most obvious ones, these being lack of need and lack of time), appear to be connected with the fact that these firms were suffering from problems on two fronts: from a lack of information, on the one hand, with regard to the needs that, in terms of capabilities and skills, are required by their human capital, and on the other, from a lack of knowledge of the training offer available (Figure 1). 
Figure 1

\section{Reasons for businesses not financing continuous training}

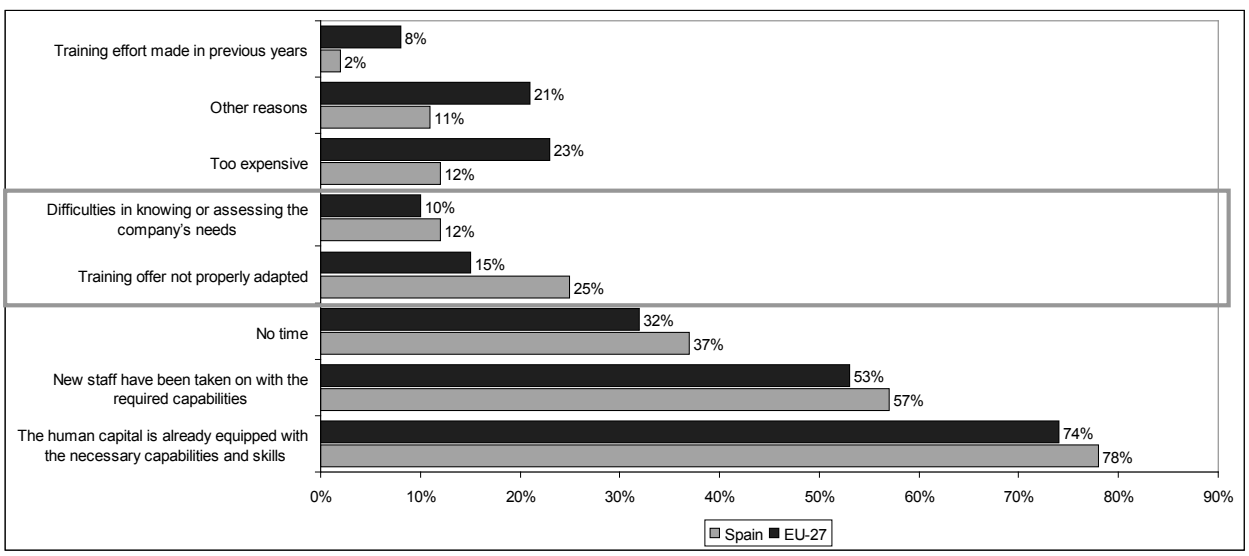

Source: Eurostat (2007)

In short, the fact that information is not uniformly and transparently available produces decision-making problems that may partly explain the differential behaviour of companies towards management training.

Consequently, actions aimed at making external and internal management training markets more transparent (quality rankings, accreditations, exchange of experiences, reference-focussed objective indicators, etc.) and at pooling knowledge as to how to carry out more efficient and more effective training actions (best practices, setting up networks of companies with similar training needs and so on), ought to be of help in taking decisions in this area. In fact, these actions could bring real investment up to the optimal levels that would be reached if firms had access to all the information they need. In this regard, rigorous investigations must be undertaken, from a normative approach, in order to concretise and rank these actions and actually clarify what it is that companies and all the other agents involved in management training can and must do to improve intensity and results.

On this basis, this paper includes a structured account of management proposals and practices on which there is greater consensus among a selected group of heads of training or human resource managers. These proposals based on theoretical arguments (Theory of human capital; Resource-based view) would be directly related to improving the intensity and results of continuous management training (CMT) activities. 


\section{CONCEPTUAL AND THEORETICAL FRAMEWORK}

\subsection{Conceptual framework}

We will consider Continuous Management Training to be the programmed set of actions carried out upon managers or trainee managers, with the aim of providing, adapting or developing knowledge, skills and attitudes that will enable them to improve their managerial capability and quality. This training may be developed both inside and outside of the firm, by external or internal trainers, during work or leisure time, on the initiative of the company or of managers themselves.

\subsection{Theoretical framework}

From a theoretical viewpoint, our analysis of improvements in CMT, from a company perspective, is undertaken in the light of different important theoretical contributions, some of which already have a classical status, which will assist us in comprehending, explaining and acting upon this phenomenon. In this regard, the two main theoretical referents for our analysis were the Theory of human capital and the Resource-based view.

\subsubsection{Theory of human capital}

The most recognised theoretical contribution within the field of training is the theory of human capital (Becker, 1964; Schultz, 1961). This theory presents training as an investment made by economic agents with the expectation of it being recovered afterwards in the shape of greater income levels stemming from higher productivities achieved due to such higher training. This theory justifies not only training investment made in managerial resources by companies, but also their cautious behaviour when unsure as to whether they will be able to recover that investment when faced with eventual opportunistic behaviours by the managers concerned (such as leaving the company or failing to transmit the knowledge learnt).

As theory within the economic and business sphere has actually progressed in terms of knowledge of training investment problems, it has also become more relevant to consider those stemming from information asymmetry. In particular, opportunist behaviours associated with training and, specifically, problems of adverse selection and moral hazard. New Institutional Economics has made striking contributions in this regard (Akerlof, 1970; Stiglitz and Weiss 1981; Jensen and Meckling, 1976; Williamson, 1975), while some of them even concentrate on the labour market (Spence, 1973; Waldman, 1984; Waldman, 1990; Bernhardt, 1995).

Thus, asymmetric information in the management training context can set off problems and behaviours connected with precontractual opportunism (adverse selection) or with postcontractual opportunism (moral hazard). When a company suffers from a lack of information about its real management training needs, or regarding the quality of the providers of training, or it does not have in-depth knowledge as to which members of the manage- 
ment team are the most "appropriate" individuals to initiate a training action, the capacity of such a training action to generate value is cast in doubt and we are facing a problem of adverse selection. When the company lacks information about the ex-post behaviour of individuals who are recipients of training investment, in that it does not know for certain that they will not have opportunist behaviours, such as leaving the firm once their value as professionals has increased thanks to the training investment, not sharing what has been learnt with the company as a whole, or demanding salary increases that cancel out their increase in productivity, the possibility of the company appropriating training investment results becomes a matter of doubt and we are facing a problem of moral hazard.

All of the foregoing sets in motion a series of behaviours that lead to restrictive consequences on the volume of training performed, falling below training that would be carried out if such information asymmetries did not exist between the parties involved (company, managers and training providers) (Brunello and De Paola, 2004; Landeta et al., 2009).

From this perspective, an increase in the information level and knowledge possessed by companies and managers concerning the variety and quality of the different existing training options in the management training market, both external and internal; an improvement in the company's knowledge of the interests, capability and needs of their managers; and a reduction in the risk perceived both by company and managers of the other party indulging in opportunistic behaviours once the training is over, all impact favourably so that the training finally given will be what the parties involved really need.

\subsubsection{Resource-based view}

The starting premise of the Resource-based view (among others: Amit and Schoemaker, 1993; Barney, 1986; 1991; Grant, 1991 and Peteraf, 1993), meanwhile, is that each enterprise possesses a set of resources and capabilities that makes it different from other companies and achieves different degrees of efficiency and competitiveness. Of late, many researches (Lado and Wilson, 1994; Wright et al., 1994; Boxall, 1996; Kamoche, 1996; Mueller, 1996; Barney and Wright, 1998) have suggested that people make up the resource with the greatest potential to furnish solid sustainable competitive advantages, due to the fact that their particular characteristics make them a resource that is especially difficult to imitate or replicate. From the point when a manager establishes company strategy, and knowing that no two managers are the same, s/he may be considered to be a strategic factor, even though not all managers are equally "strategic" in all situations: the value of the managerial resource increases in the degree to which it is able to generate more profit for the company (not just for itself); it is harder to be replaced; it is harder for competitors to imitate; and less likely to change company. In consequence, to obtain above-normal performances it is necessary to employ (develop, train, apply and retain) managerial resources efficiently, paying attention to the circumstances that affect the particular value each manager has for their organisation. Managers are, therefore, considered to be a strategic resource that must be retained and developed (Castanias and Helfat, 1991; 2001).

From this perspective, if managers are increasingly considered a strategic resource, and training regarded as a useful tool for developing, motivating and retaining them, combined with professional strategic management of this managerial resource, this will presumably contribute to greater training effort, both by companies and by managers themselves. 


\section{METHODOLOGY}

\subsection{Methodology applied}

Working from the theoretical framework proposed, in order to achieve the study objective we combined the literature review and the theoretical deduction made by the research team itself with the employment of various qualitative techniques, applied to a selected group of experts with great experience and responsibility in management training.

The actions carried out were the following, in sequential order:

Selection by the authors of this study of a set of proposals aimed at optimising company behaviour in the area of CMT, via experiences gathered in the literature analysed and through the deduction derived from the theoretical framework employed.

Discussion of the theoretical referential proposed, of its main constituent variables and of the proposals that stem from its application (Discussion Group).

Obtaining of new proposals from the perspective applied by the company, for improvement in CMT (Nominal Group Technique).

Assessment of the interest and feasibility of the different proposals or good practices collected, keeping open the option of acquiring new propositions (Delphi Method).

This combination of the three qualitative techniques indicated, brought together as a methodological unit aimed at obtaining information from experts in professional contexts, has recently been termed Hybrid Delphi (Landeta et al., 2011).

With the application of this methodology we sought to get the most out of the potentialities of these qualitative research techniques, whilst reducing the limitations they have when used individually. Hybrid Delphi is specially conceived to be applied with professional experts who work in real contexts. In addition, this methodology makes it possible to involve a cadre of active professionals (HR managers, in our case) in the research process so that they continually test and enrich the outcomes of the different stages of investigation.

\subsection{Selection of the group of experts}

The members of the expert panel selected were the heads of training or, in some cases, HR managers, of companies of 50 or more workers rooted in the Autonomous Community of the Basque Country (ACBC) that, in an empirical study on Company behaviour vis-à-vis CMT (Landeta et al., 2007), had been shown to reach the highest levels of readiness to invest in manager training (highest investment in management training, highest relative number of managers trained per year, and highest commitment to management training -assumption of costs and assignment of working hours).

The intention was therefore that, in the composition of the panel, companies should be represented that, because of their firm pro-training commitment, were likely to develop advanced practices enabling optimisation of continuous training management (need diagnostics, evaluation mechanisms, etc.), to guarantee the appropriability of the results generated by the investment made or, simply, to be enterprises whose positive concern shown towards training lent their opinions the necessary authority to be heeded in a study of these characteristics. Naturally, these 
companies were represented by their managers, so the managerial view was also implicitly reflected in the proposals.

Finally, 13 experts took an active part in the dynamics proposed, this being a number that was assumable in terms of work and risk, and 12 of whom were from companies selected following the criteria described above (approximately 40 companies were classified as "high readiness", out of the total of 326 companies that took part in the quantitative study already referred to), whilst the remaining expert was from the Association for Management Progress (APD), an organisation that collaborated in this study and whose presence represents two more interest groups (apart from the companies and the managers themselves) that intervene more actively in this process: Training providers and Public agents and business associations.

\subsection{Discussion Group}

A Discussion Group (Krueger, 1994) was set up, in which 10 experts intervened, in addition to the members of the research team. These experts heard the presentation of the theoretical referent proposed to explain business behaviour vis-à-vis CMT (already explained in this article in the section Theoretical and Conceptual Framework), and of the most relevant variables that derived from this approach, plus some proposals that, through this theoretical logic, might serve to improve the efficiency and effectiveness of management training.

After these explanations, a stage of individual interventions, personal contributions and conceptual clarifications began.

The purpose of the configuration of this discussion group was to test out with training professionals the logic of analysis proposed in the study, all of whom were to share it and project their personal experiences via the same approach in the later dynamics (fundamentally based on information asymmetries between the training agents). In the discussion they showed their agreement with the validity of the theoretical framework proposed for the analysis of this study object and both their contributions and assessments were taken into account in the definitive interpretation of the results and in the final conclusions. In this regard, the group especially highlighted the importance of the variable "manager's strategic value" and, to a lesser degree, of the professional management of managerial resources and of the training opportunity cost for the firm in explaining company behaviour toward continuous management training. However, they ascribed less importance to the risk of opportunist behaviours on the part of managers. They also proposed a new variable that we had not contemplated in the study to date: the value that managers themselves confer on their training, as an explanatory variable of company behaviour.

\subsection{Nominal Group Technique (NGT)}

To motivate the contribution of interesting action proposals oriented toward improving company action around CMT, the Nominal Group Technique was utilised (Delbeq and Van de Ven, 1971; Van de Ven and Delbeq, 1971).

This technique is a structured process for capturing and aggregating opinions, in which a selected group of experts, who get together physically in the same place, contribute their ideas or experiences regarding, in this case, good CMT practices. 
The methodology of the technique mean that the experts, in silence, had to write down good practices in this field, as applied in their company or that they were aware of from other experiences. A round then began in which each expert had to outline one of the practices they had listed, after which the following expert took their turn. The rounds continued until all the experts saw expositions (made by themselves or by others) of the practices they had written down. If an expert was out of practices to describe they chose to miss their turn, although they could make a contribution in a later round if something new occurred to them.

The experts had to explain the practice until they all had a common understanding of what it consisted of, but they were not able to make assessments or strike up discussions. This methodology facilitates the structured securing of ideas and experiences from all the experts taking part, steering clear of unwanted influences due to dominant personalities and contrasts in status.

The proposals or good practices obtained (a total of 25), along with other proposals framed by the authors of this study from experiences gathered in the literature and from the deduction derived from the theoretical framework taken as a reference (a total of 15), were the object of assessment via a Delphi exercise. An additional result of this dynamic was the satisfaction displayed by the experts taking part, who were able to share their best training practices and learn one from another. This satisfaction translated into commitment to our research, and effective participation in the aforementioned Delphi exercise.

\subsection{Delphi application}

\subsubsection{Delphi Method: Characteristics}

The Delphi method is a social research technique whose object is to obtain a creditable group opinion from a group of experts. This methodology makes it possible to understand situations and interpret complex phenomena, putting in first place the experience and valuable contributions offered by the participants, who do not need to coincide either in time or in space to mutually interact (Dalkey, 1963; Linstone and Turoff, 1975; Landeta, 2002 and 2006).

The following are its main characteristics:

- It is an iterative process. The experts must be consulted at least twice concerning the same question, allowing them to rethink their answer, helped by the information they receive from the opinions of the other experts.

- The survey is carried out respecting anonymity (the experts are unaware of the identities of those making each particular contribution) in order to offset the effects produced by "leaders" and the negative influences that may be brought to bear on individual responses because of the personalities of the experts taking part. Thereby the real opinion of each expert is obtained, rather than an opinion distorted to a greater or lesser degree by the group process.

- Controlled feedback. The exchange of information between the experts is not free, but is mediated by the group coordinating the study, which means that all information that is not of relevance is eliminated. 
- Statistical group response. All the opinions form part of the final response. The questions are set so that a quantitative statistical treatment of the replies can be made.

The execution of the study with more than one round pursues a dual objective. On the one hand, to send back and share the information obtained with all who have collaborated in the study by contributing their knowledge and opinions, and, on the other, to consolidate and validate the results obtained in the initial consultation.

\subsubsection{Process}

Two rounds were performed in this application, in which thirteen experts took part; the ten experts who had participated in the Discussion Group and in the Nominal Group intervened, plus three others belonging to the group of high proclivity companies, who had expressed an interest in participating, but had not been able to attend the direct contact dynamic in the Nominal Group.

The action proposals for optimising company behaviour with regard to manager training were structured in three different sections, in accordance with their main target group:

$1^{\text {st }}$ Public agents and business associations (7 proposals)

$2^{\text {nd }}$ Training providers (2 proposals)

$3^{\text {rd }}$ Companies (31 proposals)

The questions in the questionnaire were designed so that the responses given by the experts could be statistically analysed, and were framed using a seven-point Likert scale. The experts used this to assess the importance they awarded to each of the action proposals they were presented with, in relation with their ability to effectively contribute to increasing company investment in CMT, due to their capacity to improve expectations of making training profitable for the company. The value of 7 represented maximum importance (a very useful practice for any company), 4 stood for average importance (a practice of average usefulness, or only valid for some enterprises) and 1 reflected no importance (a practice of no usefulness whatsoever). The experts were asked to try to assess the proposals from their own perspective and experience, so as to be able to determine which of them might have a greater positive influence on a larger number of companies. So, what was of interest, rather than an absolute evaluation of each technique, which would generally be high given that the propositions were provided by the experts and had worked in their companies, was a relative assessment, that is, its ranking within the set of applicable proposals for each kind of agent, and the dispersion of the responses, which gives an idea of the degree of consensus regarding its effectiveness.

Likewise, in each of the three big questionnaire sections the experts were asked for any information or comments they considered relevant concerning the questions posed and the responses given, and they were offered a chance to suggest other action proposals that had not been mentioned and that they deemed to be of importance for any of the interest groups identified.

The questionnaires, and responses from the experts, were sent using email as the communication tool. When the first questionnaire had been devised and the experts' replies had been received, the coordinating group was in charge of organising the feedback stage. The information from this feedback, which was attached for the experts along with the second round questionnaire, was of two kinds: 
- Statistical information: statistical data per item, obtained from the distribution of the responses (median, lower quartile and upper quartile).

- Additional information: this kind of information, qualitative in our case, and coming from the experts, had a dual use. On the one hand, it allowed us to better specify the formulation of particular questions (for the second questionnaire), so as to guarantee that all the experts had actually replied to the same question. And, on the other hand, it made possible the incorporation of new action proposals for each of the interest groups, so that they could be known and assessed by all the other experts in the second of the questionnaires issued.

Figure 2

Delphi Good management training practices: drafting stages

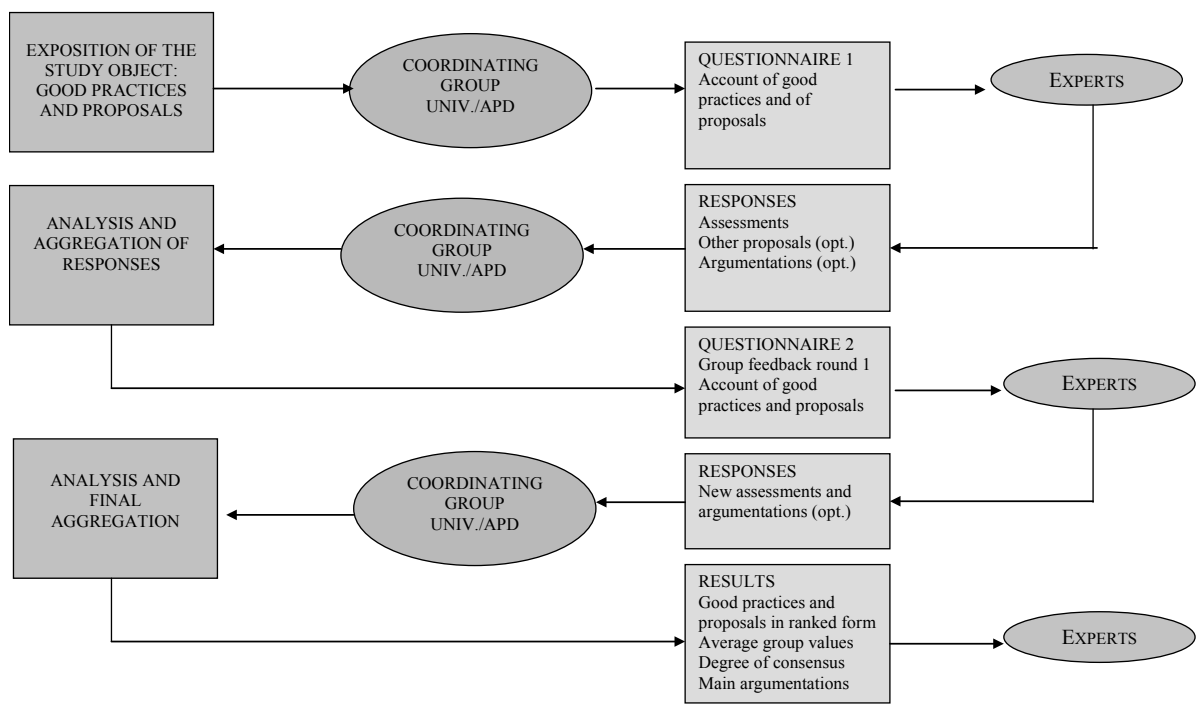

In a Delphi exercise, the number of questionnaire rounds (iterations) is variable, depending on the material to be dealt with and on the stability and degree of consensus that is being achieved. In this case, it was considered sufficient to perform only two rounds. In the second iteration, the experts are in a situation to compare their answers with those of the other experts participating, with the right to maintain their opinion or, on the contrary, alter it, in the light of the results and of the contributions and reasonings given by the rest of the experts.

The whole stage involving the dispatch and receipt of the study questionnaires took up a total of ten days for the two rounds (Figure 2). It was a relatively short time period that made it easier to maintain the interest of the experts, especially if we bear in mind that over a longer stretch of time circumstances might arise producing variations in the reality to be analysed and, correspondingly, in the panellists' evaluations. In the first round 13 experts participated, whilst in the second the number of responses was 10. 


\subsubsection{Analysis}

Finally, we statistically analysed the data for the replies to the questionnaires and, from them, the perception of the reality understudy and jointly shared with the experts. For the purposes of the statistical treatment, a question was understood to be each of the action proposals regarding which the experts had to pronounce their opinion (item). For each question (a total of 40) and iteration, indicators were calculated for central tendency (mean, median, mode, maximum and minimum) and for the dispersion/consensus of the responses of each of the experts (standard deviation and inter-quartile range). The increase in consensus was measured between rounds and the proposals for each category were ranked in accordance with the assessments obtained (median). The qualitative contributions were employed for the interpretation of the results and to draw up the conclusions.

\subsubsection{Evaluation}

In general, the quality of the development of the Delphi exercise can be deemed to be highly satisfactory:

- a sufficient number of training managers took part from outstanding companies in HR management in the Basque Country,

- they exhibited a strong degree of involvement (all the experts who participated in the Discussion Group and in the Nominal Group exercise took part in the Delphi application, plus three others who expressed an interest in being involved),

- they contributed a great deal of qualitative information, additional to that which had already been provided in the previous dynamics (they made 9 additional proposals, which completed or nuanced proposals that had been presented, and they were incorporated within those already existing and were assessed in the second round)

- the number of dropouts in the second round was low (three), and even more so considering the dates and short time periods we had to work with,

- the results were obtained in a short period of time (two weeks),

- for most of the items (78\%) a higher degree of consensus was achieved in the second than in the first round. For each item, an average of three of the experts (out of 10) modified their opinion. The experts modified their opinions and their positions came closer as a consequence of the exchange of information encouraged by the Delphi methodology. The Intraclass Correlation Coefficients for each set of items were high and, in general, higher in the second round (Table 8).

The technique was employed, therefore, in an orthodox manner, so that anonymity, iteration and qualitative and quantitative group feedback would hopefully have contributed to the experts experiencing real changes of opinion and, consequently, to changes in the group's stance, thereby attaining a more deeply pondered and shared group opinion. The purpose of the methodology utilised is that the experts themselves gauge their knowledge and change their minds, in the light of new information that reaches them in interaction with the confidence they have in their own information (Rowe and Wright, 1996). Accordingly, probable processes of social desirability and of group influence for undesired reasons, common in group techniques, are less likely to have a significant influence on the results, although the approach certainly does not manage to completely eliminate these risks (Bardecki, 1884). 


\section{RESULTS}

The good practice proposals obtained from the experts (25) and contributed by the authors of this work, drawn from the literature analysed and from the theoretical framework employed (15) were classified in line with their target collectives: public agents and business associations (Table 1), training providers (Table 2) and companies (Tables 3-7). The majority were proposals or good action practices aimed at companies (31), allowing us to sub-classify them into the following areas or subjects:

i. Proposals associating training and business strategy (Table 3 )

ii. Cooperation and company networks (Table 4)

iii. Improvement of CMT management (Table 5)

iv. Proposals for the design of training actions (Table 6)

v. Reduction of risks of opportunistic behaviours between managers and company (moral hazard) (Table 7)

The 15 propositions that emerged from the theory and the literature are marked in the tables 1-7 with an asterisk. The relationship between the theoretical arguments and the proposals we define is showed in Figure 3.

The practices were ranked within their respective categories according to their median and, where the median was the same, their mean, obtained through the Delphi application. The assessments were made using a 7 point scale. The proposals with the highest medians and means in the distributions of the experts' assessments reflect a higher level of acceptance by the group as a whole and, consequently, a greater capacity to influence in improving the behaviour of organisations with regard to manager training. As absolute indicators of the degree of consensus (or, in the opposite sense, of dispersion) exhibited by the experts for each question we chose to use the Interquartile Range (IQR) of the different resulting distributions (difference between the third $\left(Q_{3}\right)$ and the first quartile $\left(Q_{1}\right)$, along with the standard deviation $\sigma$. We also employed the ICC, as a general indicator of the degree of consensus among the experts who replied in each area or subject and as an indicator of the coherence of the areas in which we grouped the proposals that they evaluated (Table 8). 


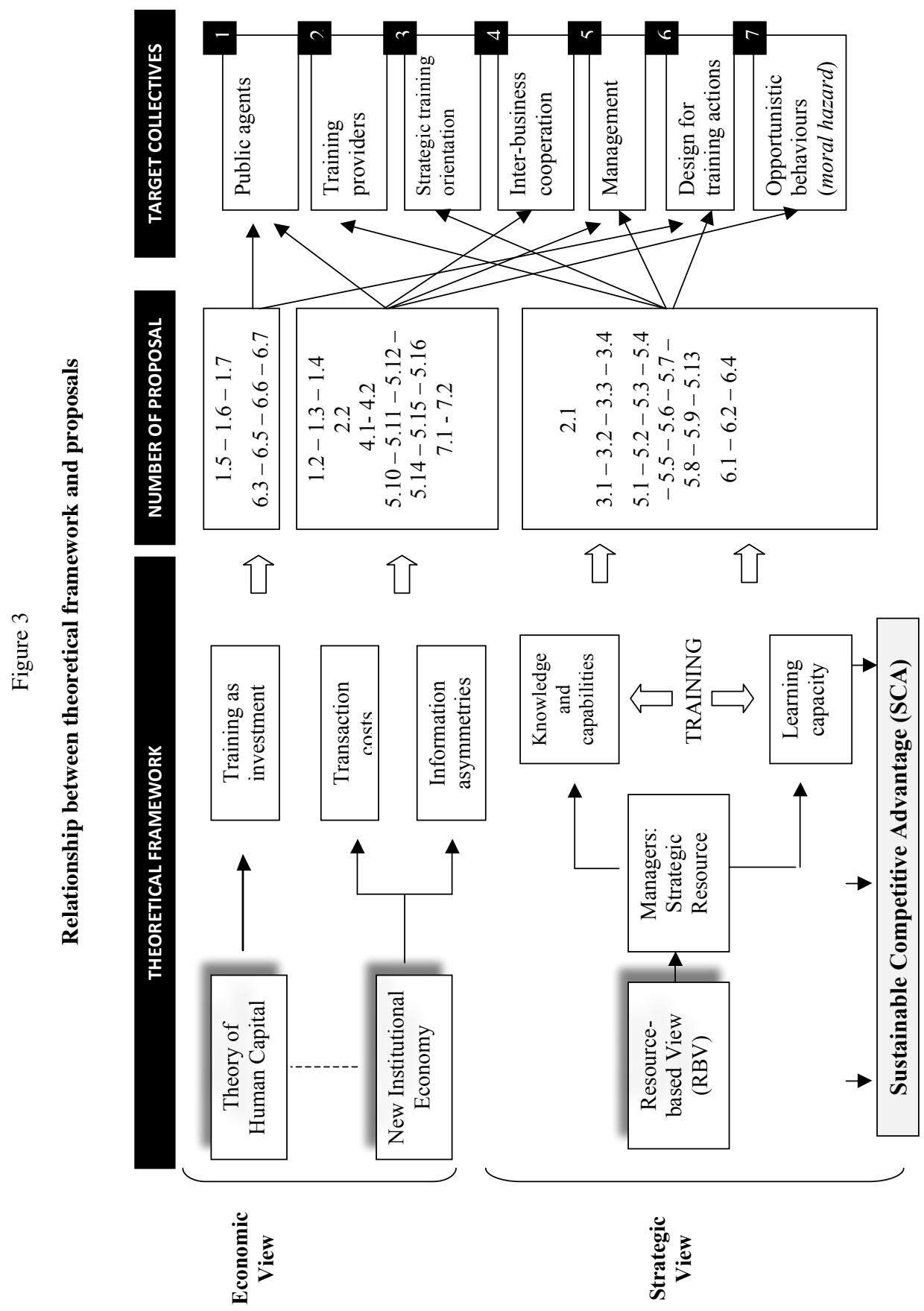


In the following sections these results are summarised:

\subsection{Action proposals for associations and public agents involved in management training}

Various action lines are proposed for associations and public agents (Table 1):

1) Associations and public agents interested in strengthening company and institutional competitiveness should carry out actions likely to formalise initiatives geared to train and equip managers with new skills and capabilities (proposal 1.1).

This involves the promotion of alliances with business associations, facilitating the development of managerial associations, the creation of company forums, etc, and, in general, supporting the formation of networks that make it possible to share control costs, improve access to information, and exchange experiences (benchmarking). These initiatives may prove interesting for all kinds of companies, and very much so in the case of SMEs. In this regard, greater effort must be made in companies that, with external help, due either to their size (e.g., SMEs) or to the sector they belong to, might markedly increase their expectations of the generation and appropriability of training results (proposal 1.3).

2) A second line of action for public agents would be to make greater efforts to disseminate, monitor and signpost external management training offer (proposal 1.2).

The management training market is very complex, with few barriers to entry, the product offered is intangible and difficult to compare, and providers appear and disappear with relative ease. Individual companies tend to lack mechanisms for ensuring a priori the quality of the service demanded. Associations and public agents can collaborate in reducing information asymmetry by furnishing mechanisms that provide information on the quality and contents of what this market offers: accreditations and validations of training companies, directories of independent suppliers, webs with assessments by companies using the services and by training providers, etc.

3) Agents involved in training should, in their respective spheres of responsibility, measure, provide references and lubricate external comparison of training efforts performed.

Companies lack valid referents concerning the degree of effort they should make in this sphere. So it is important to calculate and transmit specific information in the shape of objective indicators (training expenditure/wage bill, percentage of managers participating in training per year, annual training hours, distribution of training by type -internal, external; direct contact, on line, in company- or by subject areas -managerial skills, technical knowledge, languages...-) that are as close as possible to the actual context of company action (proposal 1.4). National and sectoral data or even information regarding groups of kindred companies are valuable references that make it possible to know the relative situation of each organisation and decide in consequence.

4) Economic assistance for the design and execution of training actions constitute an intervention by authorities and public or private organisations that might prove to be effective and recommendable, particularly in order to increase management training input in small enterprises (proposals $1.6 / 1.7$ ).

The economic and organisational effort demanded by continuous training also conditions the level of investment made on training, and affects the outlay of expenditure by companies very unevenly, especially where size is concerned. Institutions can collaborate 
efficiently through their funding, both in terms of the intensity of training intensity and in its reach.

5) Promoting scientific studies that throw into relief the keys that condition company behaviour, provide analyses and data on the real investment in training that is being carried out in different geographical and sectoral contexts, and offer valid ways of measuring and comparing the profitability of training actions, must also help to cover this existing information deficit and, consequently, take business investment towards its optimal levels (proposal 1.5).

Table 1

Ranking of the action proposals aimed at public agents and business associations

\begin{tabular}{|c|c|c|c|c|c|c|c|}
\hline & & \multicolumn{2}{|c|}{$\begin{array}{l}\text { Assessment } \\
\text { (out of 7) }\end{array}$} & \multicolumn{2}{|c|}{$\begin{array}{l}\text { Final consensus } \\
\quad\left(2^{\text {nd }} \text { round }\right)\end{array}$} & \multicolumn{2}{|c|}{$\begin{array}{l}\text { Variation of } \\
\text { consensus } \\
\left(1^{\text {st }} / 2^{\text {nd }} \text { round }\right)\end{array}$} \\
\hline & & Median & Mean & $\sigma_{2}$ & $\mathrm{IQR}_{2}$ & $\sigma_{1}-\sigma_{2}$ & $\begin{array}{l}\mathrm{IQR}_{1} \\
-\mathrm{IQR}_{2}\end{array}$ \\
\hline 1.1 & $\begin{array}{l}\text { Promoting agreements and actions with } \\
\text { professional and managers' associations to } \\
\text { resolve problems and exchange experien- } \\
\text { ces of CMT and the quality of service } \\
\text { offered by providers* }\end{array}$ & 6 & 6.2 & 0.60 & 0.8 & 0.04 & -0.5 \\
\hline 1.2 & $\begin{array}{l}\text { Controlling quality and signposting exter- } \\
\text { nal management training offer } *\end{array}$ & 6 & 5.9 & 0.54 & 0.0 & 1.02 & 1.25 \\
\hline 1.3 & $\begin{array}{l}\text { Paying special attention to SMEs in all } \\
\text { key aspects for management training } \\
\text { (funding, promotion of networks for the } \\
\text { exchange of experiences, providing infor- } \\
\text { mation on offer suitable for SMEs...)* }\end{array}$ & 6 & 5.6 & 0.80 & 1.0 & 0.12 & 0.25 \\
\hline 1.4 & $\begin{array}{l}\text { Providing references and facilitating ex- } \\
\text { ternal comparison via focussed objective } \\
\text { indicators (sectoral statistics, broken } \\
\text { down by size or activity, on business tra- } \\
\text { ining expenditure, management training } \\
\text { hours per year, \% of managers trained, } \\
\text { kind of training carried out...)* }\end{array}$ & 5.5 & 5.5 & 0.50 & 1.0 & 0.12 & 0.00 \\
\hline 1.5 & $\begin{array}{l}\text { Fostering studies to analyse and optimise } \\
\text { CMT investment* }\end{array}$ & 5 & 4.7 & 1.00 & 0.8 & 0.23 & 0.25 \\
\hline 1.6 & $\begin{array}{l}\text { Encouraging specific managerial training } \\
\text { programmes (by sector, areas of need...)* }\end{array}$ & 5 & 4.6 & 1.20 & 0.8 & 0.17 & 0.75 \\
\hline 1.7 & $\begin{array}{l}\text { Economic aid for the design and execu- } \\
\text { tion of training actions (subsidies, advan- } \\
\text { tageous financing conditions ...) }\end{array}$ & 4 & 4.4 & 1.11 & 1.0 & 0.43 & 0.25 \\
\hline
\end{tabular}

$\sigma_{\mathrm{i}}=$ Standard Deviation; $\mathrm{IQR}=$ Interquartile Range 


\subsection{Action proposals for training providers}

Two main action lines are proposed (Table 2)

1) Training providers should also promote actions that make it possible to increase training market transparency (rankings, accreditations, groupings of providers with internal quality regulations...).

2) They should, naturally, also improve the quality and adaptation of their products and services to the changing needs of companies and of their managers.

With both actions they will contribute to increasing global demand for their products, once any adverse selection that might be occurring has been reduced, produced by the inability of companies and of managers to discriminate the quality and characteristics of the various offers that make up the training market.

Table 2

Ranking of action proposals aimed at training providers

\begin{tabular}{|c|c|c|c|c|c|c|c|}
\hline & & \multicolumn{2}{|c|}{$\begin{array}{l}\text { Assessment } \\
\text { (out of 7) }\end{array}$} & \multicolumn{2}{|c|}{$\begin{array}{l}\text { Final con- } \\
\text { sensus } \\
\left(2^{\text {nd }} \text { round }\right)\end{array}$} & \multicolumn{2}{|c|}{$\begin{array}{l}\text { Variation of } \\
\text { consensus } \\
\left(1^{\text {st }} / 2^{\text {nd }} \text { round }\right)\end{array}$} \\
\hline & & Median & Mean & $\sigma_{2}$ & $\mathrm{IQR}_{2}$ & $\sigma_{1}-\sigma_{2}$ & $\begin{array}{l}\mathrm{IQR}_{1} \\
-\mathrm{IQR}_{2}\end{array}$ \\
\hline 2.1 & $\begin{array}{l}\text { Improving the quality and adaptation of the } \\
\text { offer to managerial needs: skills, values, } \\
\text { new perspectives, experiences, relations, } \\
\text { training of personal value...* }\end{array}$ & 6 & 5.9 & 0.54 & 0.00 & 0.10 & 0.25 \\
\hline 2.2 & $\begin{array}{l}\text { Promoting actions that increase the trans- } \\
\text { parency and quality of the training market } \\
\text { (quality rankings, accreditations, groupings } \\
\text { of providers with internal quality regula- } \\
\text { tions...)* }\end{array}$ & 6 & 5.7 & 0.64 & 1.00 & 0.19 & 0.25 \\
\hline
\end{tabular}

$\sigma_{\mathrm{i}}=$ Standard Deviation $; \mathrm{IQR}=$ Interquartile Range

\subsection{Action proposals for companies}

The action lines proposed for companies are oriented in different directions:

1.- Alignment of managerial training and development policies with the company's strategy and culture (Table 3).

This strategic management of training activities, development and refinement is in harmony with the strategic value that scientific literature and business declarations confer on managers. 
Table 3

Ranking of action proposals aimed at companies: strategic training orientation

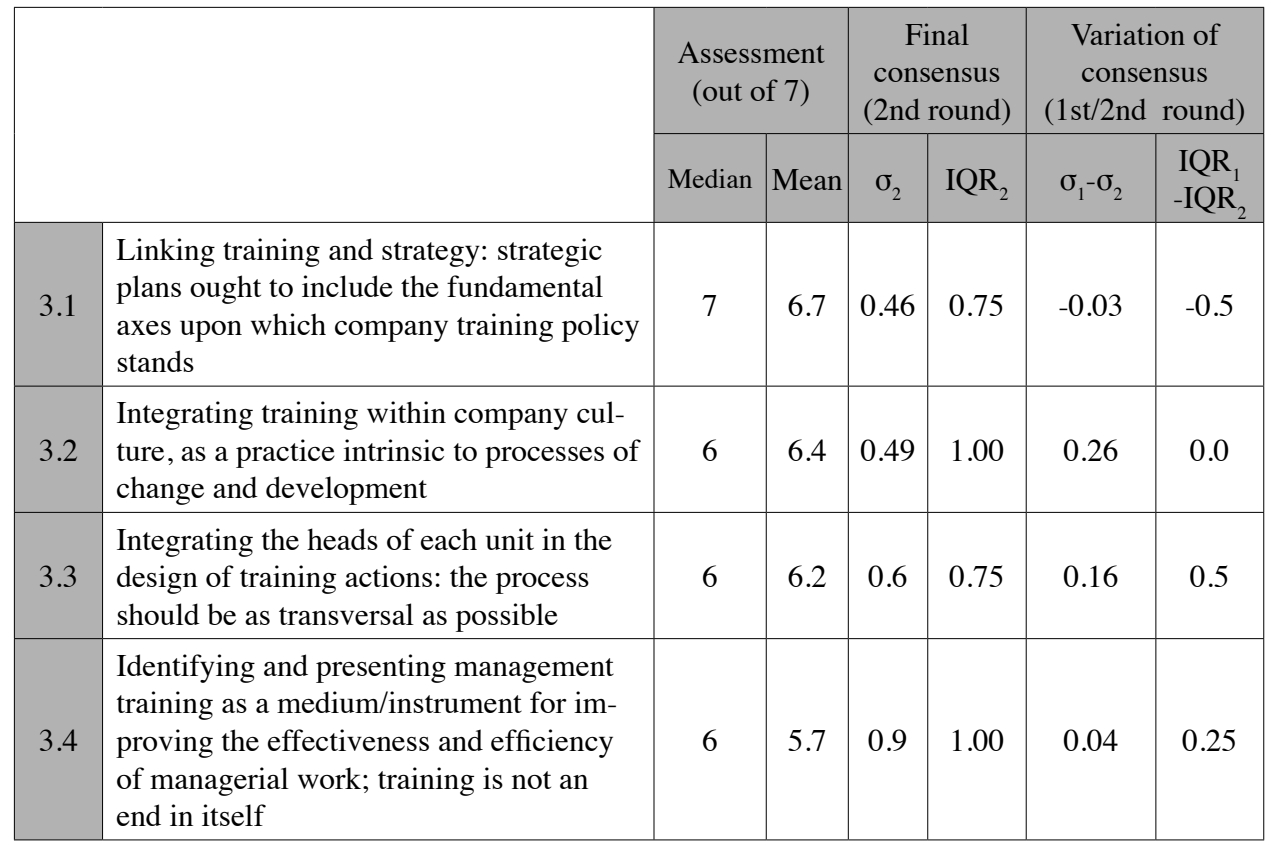

$\sigma_{\mathrm{i}}=$ Standard Deviation: $\mathrm{IQR}=$ Interquartile Range

2.- Cooperation with other companies to maximise the effectiveness of management training (Table 4).

The creation of networks/forums of companies with similar characteristics and needs (by sector, activity, size, etc.) is a valuable way of obtaining specific valid references for inter-business comparison and for improvement, as well as for the exchange of experiences and good practices. 
Table 4

Ranking of action proposals aimed at companies: inter-business cooperation

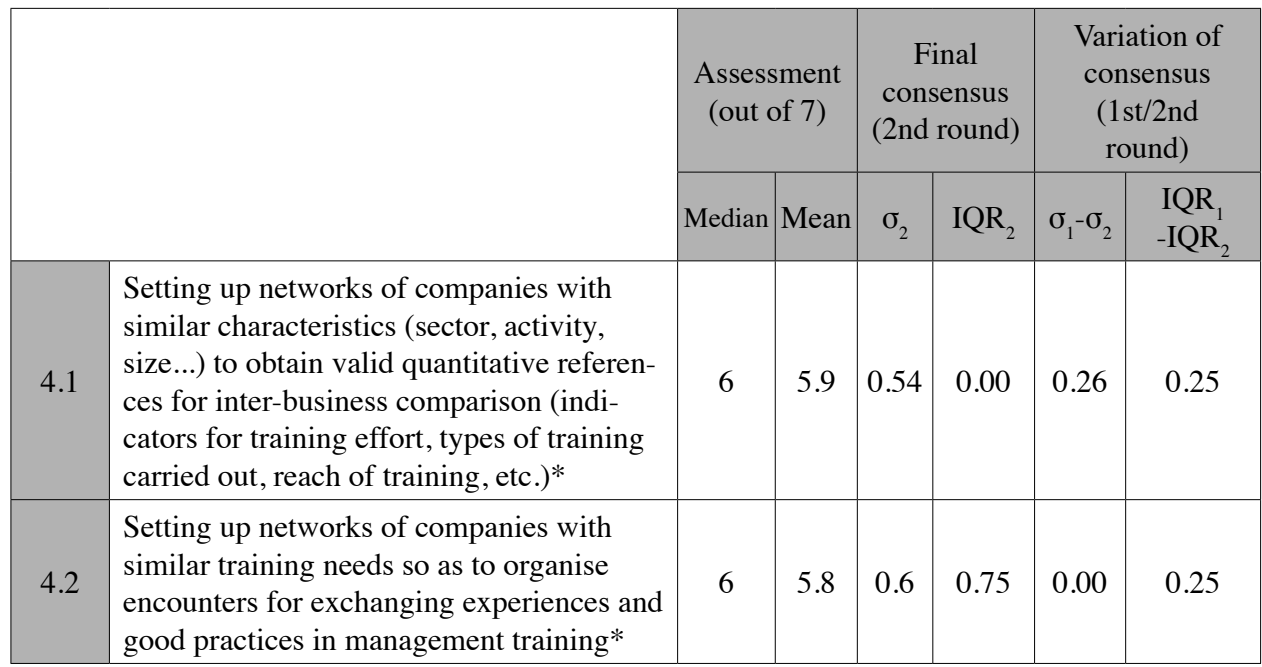

$\sigma_{\mathrm{i}}=$ Standard Deviation; $\mathrm{IQR}=$ Interquartile Range

3.- Improvement in CMT management, in several ways (Table 5)

a) Implementation of defined manager training and development policies, with suitable planning of managerial resources, as well as diagnoses adjusted to new needs, developments and personalised monitoring and evaluation processes.

All these actions should reduce information asymmetry between the parties, diminishing the risk of the appearance of phenomena of adverse selection and moral hazard, and they ought, in consequence, to increase the company's expectation of the generation and appropriability of training results.

b) Encouraging the active involvement of all internal company agents associated with management training.

The involvement of "top management", of the heads of different units or areas, and of managers themselves in their training and in that of their subordinates is fundamental. It is a managerial responsibility to take charge of one's own and one's subordinates' training; managers should also be assessed for the development of this activity, as example constitutes a fundamental avenue of teaching and training, and internal benchmarking is a practice within the reach of companies that should be used to their best advantage.

c) In particular circumstances (that is to say, not as a general rule), it may be advisable to seek support from agents and external drivers so as to invest the whole process of diagnosis, development, monitoring and evaluation of management training with greater professionalism and commitment, although management and final responsibility must, at the end of the day, always be internal.

d) The promotion of training and internal learning. 
Exchanges of experiences and knowledge between company managers, training run by managers from the same company, training by "example", and so on, are powerful and efficient mechanisms of internal training that the company can promote and encourage.

Table 5

Ranking of the action proposals aimed at companies: improvements in management

\begin{tabular}{|c|c|c|c|c|c|c|c|}
\hline & & \multicolumn{2}{|c|}{$\begin{array}{l}\text { Assessment } \\
\text { (out of 7) }\end{array}$} & \multicolumn{2}{|c|}{$\begin{array}{l}\text { Final } \\
\text { consensus } \\
\left(2^{\text {nd }} \text { round }\right)\end{array}$} & \multicolumn{2}{|c|}{$\begin{array}{l}\text { Variation of } \\
\text { consensus } \\
\left(1^{\text {st }} / 2^{\text {nd }} \text { round }\right)\end{array}$} \\
\hline & & Median & Mean & $\sigma_{2}$ & $\mathrm{IQR}_{2}$ & $\sigma_{1}-\sigma_{2}$ & $\begin{array}{l}\mathrm{IQR}_{1} \\
-\mathrm{IQR}_{2}\end{array}$ \\
\hline 5.1 & $\begin{array}{l}\text { Not using external agents. Involving ma- } \\
\text { nagers and making them responsible for } \\
\text { their own and their subordinates' training }\end{array}$ & 6.5 & 6.2 & 0.87 & 1.75 & 0.55 & -0.5 \\
\hline 5.2 & $\begin{array}{l}\text { Planning management training. Persona- } \\
\text { lised plans }\end{array}$ & 6 & 6.2 & 0.6 & 0.75 & 0.3 & 1.25 \\
\hline 5.3 & $\begin{array}{l}\text { Internal benchmarking. Exchange of } \\
\text { knowledge and experiences between } \\
\text { company managers. Internal training } \\
\text { provided by successful managers }\end{array}$ & 6 & 6.2 & 0.6 & 0.75 & 0.02 & 0.25 \\
\hline 5.4 & $\begin{array}{l}\text { Making diagnoses of managerial needs } \\
\text { and competences* }\end{array}$ & 6 & 6.1 & 0.83 & 1.75 & 0.25 & -0.5 \\
\hline 5.5 & $\begin{array}{l}\text { Making career plans for managers with } \\
\text { a high professional profile (normally } \\
\text { young managers)* }\end{array}$ & 6 & 6.1 & 0.94 & 1.00 & 0.07 & 0.25 \\
\hline 5.6 & $\begin{array}{l}\text { Stimulating "individual reflection" } \\
\text { among managers in their own training } \\
\text { process. Getting managers themselves to } \\
\text { be ultimately responsible for their perso- } \\
\text { nal and professional retraining }\end{array}$ & 6 & 6 & 0.63 & 0.00 & 0.43 & 1.00 \\
\hline 5.7 & $\begin{array}{l}\text { Involvement of top management in the } \\
\text { managerial training process }\end{array}$ & 6 & 6 & 1,41 & 1.00 & $-0,09$ & 0.0 \\
\hline 5.8 & $\begin{array}{l}\text { Measurement of strategic capabilities } \\
\text { and their subsequent evolution }\end{array}$ & 6 & 5.7 & 0.78 & 0.75 & 0.40 & 0.50 \\
\hline 5.9 & $\begin{array}{l}\text { Technical convention knowledge ex- } \\
\text { change: internal knowledge management } \\
\text { presented as day training. Becoming } \\
\text { facilitators of the exchange of internal } \\
\text { knowledge contained within the com- } \\
\text { pany }\end{array}$ & 6 & 5.5 & 1.69 & 0.00 & -0.62 & 2.00 \\
\hline 5.10 & $\begin{array}{l}\text { Continuous training management at } 3 \text { le- } \\
\text { vels: Design, Follow-up and Assessment } \\
\text { of training actions carried out }\end{array}$ & 5 & 5.1 & 0.94 & 1.50 & 0.3 & 0.00 \\
\hline
\end{tabular}




\begin{tabular}{|c|l|l|l|l|l|l|l|}
\hline 5.11 & $\begin{array}{l}\text { Training evaluation at three levels (the } \\
\text { company, the person receiving the trai- } \\
\text { ning, the person providing the training }\end{array}$ & $\mathbf{5}$ & $\mathbf{4 . 9}$ & 0.70 & 0.75 & 0.76 & 1.25 \\
\hline $\begin{array}{l}\text { Possessing training heads who minimi- } \\
\text { se information asymmetries between } \\
\text { the training market, the company and } \\
\text { managers (they must know the needs and } \\
\text { potentials of these three agents) }\end{array}$ & $\mathbf{5}$ & $\mathbf{4 . 9}$ & 1.22 & 1.75 & -0.18 & 0.25 \\
\hline $\begin{array}{l}\text { "Visual" management of management } \\
\text { training: each manager is assigned trai- } \\
\text { ning responsibilities that s/he must cover } \\
\text { and anyone may monitor the degree } \\
\text { to which they are satisfied thanks to a } \\
\text { colour code (red: not started yet, green: } \\
\text { already carried } \text { out...) which is publicly } \\
\text { displayed }\end{array}$ & $\mathbf{5}$ & $\mathbf{4 , 3}$ & 1.68 & 2.50 & -0.49 & -0.50 \\
\hline $\begin{array}{l}\text { Use of agents and external drivers to } \\
\text { carry out the diagnostic process, deve- } \\
\text { lopment and evaluation of management } \\
\text { training }\end{array}$ & $\mathbf{4}$ & $\mathbf{3 . 9}$ & 1.50 & 2.00 & 0.00 & 0.00 \\
\hline $\begin{array}{l}\text { Use of agents and external drivers to } \\
\text { perform yearly monitoring of the deve- } \\
\text { lopment and successes of the training } \\
\text { planned }\end{array}$ & $\mathbf{3 . 5}$ & $\mathbf{3 . 7}$ & 1.45 & 2.00 & 1.75 & -0.50 \\
\hline $\begin{array}{l}\text { Using external agents or people from } \\
\text { inside the company who are following } \\
\text { up the training groups, ensuring that the } \\
\text { scheduled commitments are met }\end{array}$ & $\mathbf{3 . 5}$ & $\mathbf{3 . 5}$ & 1.50 & 2.50 & 0.00 & -0.50 \\
\hline
\end{tabular}

$\sigma_{\mathrm{i}}=$ Standard Deviation $; \mathrm{IQR}=$ Interquartile Range

4.- Special attention must be given to the design of training courses for groups of managers who will share training experiences. The designs ought to differ in line with the contents, participants and objetives of the courses (Table 6).

These groups ought to have interests in common and be able to learn from one another, whether they be from the same company or not, but it is important that they have no reluctance to learn and teach in common. 
Table 6

Ranking of the action proposals aimed at companies: design for training actions

\begin{tabular}{|c|c|c|c|c|c|c|c|}
\hline & & \multicolumn{2}{|c|}{$\begin{array}{l}\text { Assessment } \\
\text { (out of } 7 \text { ) }\end{array}$} & \multicolumn{2}{|c|}{$\begin{array}{l}\text { Final } \\
\text { consensus } \\
\left(2^{\text {nd }} \text { round }\right)\end{array}$} & \multicolumn{2}{|c|}{$\begin{array}{l}\text { Variation of } \\
\text { consensus } \\
\left(1^{\text {st }} / 2^{\text {nd }} \text { round }\right)\end{array}$} \\
\hline & & Median & Mean & $\sigma_{2}$ & $\mathrm{IQR}_{2}$ & $\sigma_{1}-\sigma_{2}$ & $\begin{array}{l}\mathrm{IQR}_{1} \\
-\mathrm{IQR}_{2}\end{array}$ \\
\hline 6.1 & $\begin{array}{l}\text { Open courses with managers from different } \\
\text { companies who share the same needs, } \\
\text { bypassing inhibitions due to internal diffe- } \\
\text { rences in status }\end{array}$ & 6 & 6 & 0.63 & 0.00 & 0.18 & 0.25 \\
\hline 6.2 & $\begin{array}{l}\text { Formulation of "training itineraries" (tra- } \\
\text { ining through a diversity of formulas that } \\
\text { are flexible, more global, short in length, } \\
\text { scheduled within the managerial agenda, } \\
\text { satisfying a variety of needs and making } \\
\text { training a permanent, customary, though } \\
\text { intermittent activity) }\end{array}$ & 6 & 5.9 & 0.70 & 0.75 & 0.20 & 0.50 \\
\hline 6.3 & $\begin{array}{l}\text { Courses with managers from the same } \\
\text { company who share the same needs, but } \\
\text { belong to different business units }\end{array}$ & 6 & 5.8 & 0.75 & 1.00 & 0.01 & 0.25 \\
\hline 6.4 & $\begin{array}{l}\text { Training by "example". Promoting mana- } \\
\text { gerial learning through access to observing } \\
\text { the way "exemplary" managers act }\end{array}$ & 6 & 5.8 & 1.40 & 0.75 & -0.14 & 0.75 \\
\hline 6.5 & $\begin{array}{l}\text { Courses with managers from the same } \\
\text { company who share the same needs }\end{array}$ & 5 & 5.1 & 0.70 & 0.00 & 0.06 & 1.00 \\
\hline 6.6 & $\begin{array}{l}\text { Promotion of specific managerial training } \\
\text { programmes (per sector, areas of need...) }\end{array}$ & 5 & 4.5 & 0.67 & 1.00 & 0.52 & 1.00 \\
\hline 6.7 & $\begin{array}{l}\text { Design of a specific intensive course for } \\
\text { company managers, to be given outside the } \\
\text { company and the city, with accommodation } \\
\text { included }\end{array}$ & 4 & 4.2 & 1.40 & 1.50 & -0.36 & -0.50 \\
\hline
\end{tabular}

$\sigma_{\mathrm{i}}=$ Standard Deviation $; \mathrm{IQR}=$ Interquartile Range

1. It is desirable to establish explicit agreements on commitments adopted by both parties (managers and company) with regard to investment made in this training and the repercussions it has on the organisation (Table 7). These agreements or contracts can be concretised through the signing of clauses, although it is in general better to keep them running exclusively on the basis of commitment and trust.

All these actions should reduce information asymmetry between the parties, diminishing the risk of the appearance of phenomena of adverse selection and moral hazard, and they ought, in consequence, to increase the company's expectation of the generation and appropriability of training results. 
Table 7

Ranking of action proposals aimed at companies: minimising opportunistic behaviours (moral hazard)

\begin{tabular}{|c|c|c|c|c|c|c|c|}
\hline & \multicolumn{2}{|c|}{$\begin{array}{l}\text { Assessment } \\
\text { (out of 7) }\end{array}$} & \multicolumn{2}{|c|}{$\begin{array}{l}\text { Final } \\
\text { consensus } \\
\left(2^{\text {nd }} \text { round }\right)\end{array}$} & \multicolumn{2}{|c|}{$\begin{array}{l}\text { Variation of } \\
\text { consensus } \\
\left(1^{\text {st }} / 2^{\text {nd }}\right. \\
\text { round })\end{array}$} \\
\hline & & Median & Mean & $\sigma_{2}$ & $\mathrm{IQR}_{2}$ & $\sigma_{1}-\sigma_{2}$ & $\begin{array}{l}\mathrm{IQR}_{1} \\
-\mathrm{IQR}_{2}\end{array}$ \\
\hline 7.1 & $\begin{array}{l}\text { Explicit agreements between managers and } \\
\text { company concerning commitments under- } \\
\text { taken by both parties in the area of inves- } \\
\text { tment in continuous training, meaning that } \\
\text { after carrying out a training action there is a } \\
\text { personal commitment from the participants } \\
\text { (company and managers), subject to evalua- } \\
\text { tion, so that what is learnt is somehow fed } \\
\text { back to the organisation* }\end{array}$ & 6 & 5.5 & 1.12 & 0.75 & 0.07 & 0.50 \\
\hline 7.2 & $\begin{array}{l}\text { Formalisation of permanence clauses, to } \\
\text { guarantee the permanence in the company } \\
\text { of trained managers during a specified time } \\
\text { period } *\end{array}$ & 3 & 2.9 & 1.38 & 1.50 & 0.16 & -0.50 \\
\hline
\end{tabular}

$\sigma_{\mathrm{i}}=$ Standard Deviation $; \mathrm{IQR}=$ Interquartile Range

Table 8

\section{Groups of actions proposals: Intraclass Correlation Coefficients (ICC)}

**It is not possible to calculate the ICC, because the assumptions of the reliability model are not met (negative average covariance among items)

\begin{tabular}{|c|l|c|c|c|c|}
\hline \multicolumn{2}{|l|}{} & $\begin{array}{c}\text { Number of } \\
\text { Items }\end{array}$ & Mean $(\sigma)$ & $\begin{array}{c}\text { Final Concordance } \\
\left(2^{\text {nd }} \text { iteration }\right)\end{array}$ & $\begin{array}{c}\text { Variation of } \\
\text { concordance } \\
\left(1^{\text {st }} / 2^{\text {nd }} \text { iteration }\right)\end{array}$ \\
\cline { 4 - 6 } & $\begin{array}{l}\text { Public agents and } \\
\text { business associations }\end{array}$ & 7 & $5.3(0.82)$ & 0.850 & $\mathrm{ICC}_{2}-\mathrm{ICC}_{1}$ \\
\hline 2 & Training providers & 2 & $5.8(0.59)$ & 1.00 & 0.2 \\
\hline 3 & $\begin{array}{l}\text { Strategic training } \\
\text { orientation }\end{array}$ & 4 & $6.2(0.61)$ & 0.734 & -0.08 \\
\hline 4 & $\begin{array}{l}\text { Inter-business coopera- } \\
\text { tion }\end{array}$ & 2 & $5.9(0.59)$ & $* *$ & $* *$ \\
\hline
\end{tabular}




\begin{tabular}{|c|l|c|c|c|c|}
\hline 5 & $\begin{array}{l}\text { Improvements in } \\
\text { management }\end{array}$ & 16 & $5.3(1.08)$ & 0.853 & 0.059 \\
\hline 6 & $\begin{array}{l}\text { Design for training } \\
\text { actions }\end{array}$ & 7 & $5.2(0.93)$ & 0.774 & 0.071 \\
\hline 7 & $\begin{array}{l}\text { Minimising opportunistic } \\
\text { behaviours (moral } \\
\text { hazard) }\end{array}$ & 2 & $4.2(1.17)$ & 0.962 & 0.029 \\
\hline
\end{tabular}

\section{DISCUSSION}

The experts gave high evaluations for nearly all the propositions. This was foreseeable, as most of the latter had been put forward by the professionals themselves, and had been effective in their own organisations. However, the relative assessment and dispersion in the assessments made in some responses indicate that the degree of acceptance differs between companies.

The proposals aimed at public agents and business associations $(1.1,1.2,1.3,1.4)$, and at management training suppliers (2.2), with a view to them carrying out actions geared to reduce information asymmetry in the training market and, in that regard, prevent the occurrence of adverse selection phenomena, show a high score and a strong degree of consensus. This aspect is consistent with the New Institutional Economics approach because public agents take on vital importance in the design of institutional contexts and, accordingly, in their impact on the effectiveness and efficiency of the performance of social agents (Williamson 2005). The score and consensus are lower $(m<5 ; \sigma>1)$ for actions that propose a direct intervention by these institutions in driving specific training programmes of interest, or in the assignment of specific economic aid.

The Resource-based view is a valid theoretical referent for interpreting the great importance that the experts attributed in their scores to the aligning of strategy, culture and training for managers, the latter being understood to constitute strategic resources with high competitive value (proposals 3.1, 3.2, 3.3,3.4). This assessment coincides with that made by the small group of experts who participated in the Discussion Group on the variable "manager's strategic value" and, above all, with Strategic Human Resources Management literature (among others: Shuler, 1987; Schuler and Jackson, 1987; Hendry and Pettigrew, 1992; Gubman, 1995).

The two proposals for interbusiness cooperation, with a high score and degree of consensus $(4.1,4.2)$, are aimed at diminishing training investment risk through making more valuable information available, shared among companies. This can help to better gauge investment and its profitability, increasing its effectiveness and reducing the possibility of adverse selection phenomena.

In the proposals to improve training management we observe a high score and consensus for those that are addressed toward improving management training quality management, employing techniques and methods that increase knowledge about the real training needs of each manager at any given time, about progress made in meeting those needs, and concerning the involvement of all managers in this process $(5.1-5.10)$. They are, in short, proposals that, along with those that relate CMT with strategy and culture, are geared 
toward improving the efficiency of the training process and are in line with the literature that describes the way in which training should be carried out in the firm. This efficient training management is accompanied by ongoing gathering of information concerning the level of competencies possessed by managers and about how well they match company needs. This also means that problems of adverse selection are also less likely to occur in the selection of the managers to be trained and, when the case arises, of managers to provide the training, and there tends to be an increase in the effectiveness of training investment. In this section, highly technical and presumably very costly proposals $(5.10,5.12,5.13)$ receive less acceptance $(\mathrm{m}<5.5 ; \sigma>1)$. The proposals that score worse and achieve the lowest degree of consensus $(\mathrm{m}<4.5 ; \sigma>2)$ are those that advocate turning to outside agents to develop CMT $(5.14,5.15,5.16)$. Once again, a lack of knowledge regarding the quality of the training supply and the risk of adverse selection, plus its cost, may make this investment more risky. Nonetheless, the high degree of dispersion in the answers indicates that this opinion is not unanimous, and that there are positive experiences that back such an approach. In general, it seems to be the largest enterprises that give the lowest score to seeking the services of outside agents, possibly because they have skilled internal resources at their disposal, although the limited size of the sample means that such an assertion must necessarily be viewed with much caution. It may also demonstrate a clear preference for an approach based on internal knowledge generation (Caloghirou et al, 2004), as the starting point for a combination between individual and organisational learning (Kim, 1993), as against external acquisition (Cesaroni, 2004).

In the design proposals for training actions what predominates is adjustment to the social and knowledge-related needs of managers, as a means of increasing the effectiveness of investment. The most "daring" proposals, in the sense that they would involve successful managers being analysed by the rest of their colleagues (5.4), or would entail more cost (5.7), are those that reveal less agreement in the responses $(\sigma=1.4)$.

Finally, two proposals put forward that seek to tackle eventual opportunistic behaviours by managers and/or company (6.1 y 6.2), show similar levels of consensus, but very different assessments: explicit agreements between parties are considered to be effective, formal permanence clauses far less so.

Over all, considering the number, score awarded and consensus reached for the proposals collected, it seems clear that companies pay much more attention to obtaining the information they need for management training and to properly managing it, than to covering themselves against possible opportunistic behaviours on the part of their managers. That is to say, they appear to be more concerned by the problem of adverse selection, in the sense of not making the correct decisions due to lack of information about their managers and about training suppliers, than by the problem of moral hazard, when decisions are taken without knowledge of the ultimate intentions of their managers, which may give rise to opportunistic behaviours by the latter; this is consistent with the results of previous studies by Hansson (2007) and by Landeta et al. (2009), although it must be noted that this conclusion is linked to the business and socio-economic context within which each research unfolds. 


\section{CONCLUSIONS}

In the light of the results obtained, we understand that:

1. Adaptation of company action in the area of investment in management training, so that it stands at optimal levels in relation to business needs, managers and available offer, requires transversal actions in which all the agents involved in improving this process intervene complementarily: companies, public agents and training providers

2. The effort and resources of the agents responsible for improving the competitiveness of Basque companies through training should be principally oriented toward the elimination of information deficiencies that prevent companies from reaching their optimal levels of training investment (lack of information on the quality of training offer, the potential, interest and need for managerial capacitation, external references for comparison and learning, mechanisms for improving the appropriability of training results, and the profitability of investment in training), and toward improving the quality of external and internal training. Although less determining than the above factors, it is to be recommended that there be a reduction in the cost that management training represents for companies, especially in the case of SMEs, through facilitating subsidies, advantageous financing conditions or innovative formulas that cut down on the sacrifice in time and money that some companies have to make when carrying out training actions for their managers.

3. Management training (particularly at a higher level) must be understood from a global perspective and should not centre solely on actions formally aimed at the transmission of knowledge. This level of training has a component that can be considered as "non-traditional and/or non-formal training" and is based on aspects such as the transmission of values, skills, new perspectives, the exchange of non-formal opinions with other colleagues, the establishment of contacts, and useful training for managers at a personal level. Business organisations and public agents must facilitate the right conditions for this kind of global training to take place.

4. The theoretical referents of the Theory of Human Capital (as a referent of the value of continuous training in increasing managerial and company value and, consequently, of a vision of a more fundamental nature) and of the Resources Based View (as a referent of the strategic value of continuous management training and, therefore, of a more contingent and competitive vision), seem valid for explaining the meaning of the proposals presented: improving the managerial capacity of managerial, strategic and valuable resources through actions that should reduce information asymmetry between the parties and increase the effectiveness of the time and money invested in this activity, and of the company's expectation of the generation and appropriability of training results, without costs rising to the same degree.

5. The public and private agents involved in the training process, both suppliers and demanders, agree upon the fundamental value of continuous management training and its strategic value, and specifically confer on the public agents the responsibility for a suitable institutional design for the training market.

6. Regarding the appropriability of management training results, most of the agents show themselves to be more sensitive and attentive towards the problem of adverse selection than to that of moral hazard. 
7. The degree of participation from the agents consulted and the quality of the information received confirm the value of qualitative research methods, and of Hybrid Delphi in particular, for investigations where management experience and knowledge are extremely relevant inputs.

8. Finally, this work contributes to the existing management literature a concrete set of actions oriented to improve the effectiveness of management training, obtained through an innovative methodology that integrates scientific knowledge with managerial experience, guided by a rather unusual theoretical referent in this field of study: the reduction of information asymmetries among agents involved in training activity.

\section{LIMITATIONS AND FUTURE RESEARCH}

The sample of participating companies is qualified but quite small and focused on one geographic area. It is valid for the overall objective of this work, and appropriate for application of the selected methodology, but is not valid for statistical inference. Neither allows us to analyse the proposals of the enterprises according to different classification variables: size, sector, types of training, manager levels, countries...

The studio we have carried out captures the degree of consensus of a skilled but small number of experts with regard to the capacity of actions proposed to effectively contribute to increasing company investment in CMT, due to their power to improve expectations of making training profitable for the company. However, we did not directly measure the effectiveness of these training actions, and the rankings presented must not, in consequence, be interpreted as rankings that reflect the effectiveness of such actions.

Some of these limitations could be overcome in future investigations. Studies performed over broader geographical areas and using larger samples, allowing us to differentiate company behaviours and proposals in terms of the referred variables, might contribute valuable knowledge. In addition, investigations geared to discover and assess the effectiveness of different proposals that might help to reduce existing information asymmetries between continuous training agents (firms, managers, suppliers) could prove to be of great academic and, above all, practical interest. Knowledge of these proposals should lead to a sharing of information of relevance for training decisions adopted by managers and business people, an increase in continuous training investment towards near to optimal levels and, in consequence, improvements in the profitability of companies and in the income and promotion prospects of their managers.

\section{ACKNOWLEDGMENTS}

This study forms part of a more extensive University-Business research project financed by the Basque Government and the Asociación para el Progreso de la Dirección APD, concerning company behaviour vis-à-vis continuous management training. 


\section{REFERENCES}

Adell, R., Corona, J., Guarner, F. and Torras, J., 2002. Dirigir en el siglo XXI. Deusto

Akerlof, G.A., 1970. The market of lemons: Qualitative, uncertainly and the market mechanism, Quarterly Journal of Economics, pp. 488-500.

Amit, R. and Schoemaker. P., 1993. Strategic assets and organizational rent, Strategic Management Journal, 14, pp. 33-46.

Aragón, A., Barba, I. and Sanz, R., 2003. Effects of training on business results, International Journal of Human Resource Management, 14(6), pp. 956-980.

Araujo, A., Barrutia, J., Ibáñez, P. and Landeta, J., 2001. Oferta y demanda de formación en gestión para directivos en el ámbito de la CAPV. Bilbao: Cluster del Conocimiento en Gestión Empresarial y Ediciones PMP.

Araujo, A., Ibáñez, P., Landeta, J. and Ranguelov, S., 2003. Análisis de la flexibilidad de la oferta de formación en gestión del País Vasco, Cuadernos de Gestión, 3(1 y 2), pp. 101-119.

Bardecki, M.J., 1984. Participants' response to the Delphi Method: An attitudinal perspective, Technological Forecasting \& Social Change, 25, pp. 281-292.

Barney, J., 1991. Firm resources and sustained competitive advantage, Journal of Management, 17, pp. 31-46.

Barney, J. and Wright, P.M., 1998. On becoming a strategic partner: The role of human resources in gaining competitive advantage, Human Resource Management, 37(1), pp. 31-46.

Barney, J.B., 1986. Strategic factor markets: Expectations, luck and business strategy, Management Science, 32(1), pp. 1231-1241.

Becker, G.S., 1964. Human Capital, Princeton, N.J: Princeton University Press.

Bernhardt, D., 1995. Strategic Promotion and Compensation. Review of Economic Studies, 62, pp. 315-339

Boxall, P.F., 1996. The strategic HRM debate and the resource-based view of the firm, Human Resource Management Journal, 6(3), pp. 59-75.

Brunello, G., and De Paola, M., 2004. Market Failures and the Under-provision of Training. Brussels: OECD Seminar on Human Capital and Labour Market Performance.

Caloghirhou,Y., Kastelli, I. and Tsakanikas, A., 2004. Internal Capabilities and external knowledge sources: Complements or substitutes for innovative performance, Technovation, 24, pp. 29-39

Castanias, R.P. and Helfat, C.E., 1991. Managerial resources and rents. Journal of Management, 17, pp. 155-157.

Castanias, R.P. and Helfat, C.E., 2001. The managerial rents model: Theory and empirical analysis, Journal of Management, 27, pp. 661-678.

Cedefop. European Centre for Development of Vocational Training, 2009. Modernising vocational education and training. Fourth report on vocational education and training research in Europe: Synthesis report. Luxembourg: Cedefop Reference series. Publications Office of the European Union.

Cedefop. European Centre for Development of Vocational Training, 2004. Learning for employment. Second report on vocational education and training research in Europe: Synthesis report. Lusembourg: Cedefop Reference series. Publications Office of the European Union. 
Cesaroni, F., 2004. Technological Outsourcing and Product Diversification: do Markets for Technology affect Firms' Strategies?. Research Policy, 33, pp. 1547-1564.

Dalkey, N. and Helmer, O., 1963. An experimental application of the Delphi Method to use of experts, Management Sciences, 9, pp. 458-467.

Delbeq, A. L. and Van de Ven, A.H., 1971. A group process model for problem identification and solving, Journal of Applied Behavioral Science, 7(3), pp.466-492.

Eurostat, 2007. Continuing training in enterprises in Europe - Results of the third European Continuing Vocational Training Survey in enterprises, Luxembourg: Eurostat Working Papers.

Garcia Erquiaga, E, 2007. Formación directiva y capacidad competitiva: Entrenando para el éxito empresarial, Información Comercial Española ICE, 838, pp. 157-168

Grant, R.M., 1991. The resource-based theory of competitive advantage: Implications for strategy formulation, California Management Review, 33(3), pp. 114 -135.

Gubman, E.L., 1995. Aligning People Strategies with Customer Value, Compensation \& Benefits Review, 27(1), pp. 15-22.

Hansson, B., 2007. Company-based determinants of training and the impact of training in company performance: Results from an international HRM survey, Personnel Review, 36, pp. 311-331.

Hendry, C. and Pettigrew, A., 1992. Patters of Strategic Change in Development of Human Resource Management, British Journal of Management, 3(3), pp. 137-156.

Holmstöm, B., 1982.Moral Hazard in teams, Bell Journal of Economics, 13, pp. 324-340.

Jensen, M.C. and Meckling, W.H., 1976. Theory of the firm: managerial behavior, agency costs and ownership structure, Journal of Financial Economics, 3, pp. 305-360.

Kamoche, K., 1996. Strategic human resource management within a resource-capability view of the firm, Journal of Management Studies, 33(2), pp. 213-233.

Kamoche, K. and Mueller, F., 1998. Human resource management and the appropriation-learning perspective, Human Relations, 51, pp. 1033-1060.

Kim, D.H., 1993. The link between individual and organizational learning, Sloan Management Review, 33, pp. 37-50.

Krueger, R. A., 1994. Focus Groups: A practical guide for applied research. (2nd ed.). Thousand Oaks, CA: Sage.

Lado, A.A. and Wilson, M.C., 1994. Human resource system and sustained competency-based perspective, Academy of Management Review, 19(4), pp. 699-727.

Landeta, J., 2002. El método Delphi. Una técnica de previsión del futuro. Barcelona: Ariel.

Landeta, J., 2006. Current validity of the Delphi method in social sciences, Technological Forecasting and Social Change, 73, pp. 467-482.

Landeta, J., Barrutia, J., Araujo, A. and Hoyos, J., 2007. Claves del comportamiento de la empresa respecto a la formación continua de sus directivos, Pamplona: Thomson-Civitas.

Landeta, J., Barrutia, J. and Hoyos, J., 2009. Management turnover expectations: a variable to explain company readiness to engage in continuous management training. The International Journal of Human Resource Management, 20(1), pp. 164-185.

Landeta, J., Barrutia, J. and Lertxundi, A., 2011. Hybrid Delphi: A methodology to facilitate contribution from experts in professional contexts, Technological Forecasting \& Social Change. 78, pp. 1629-1642. 
Linstone, H. and Turoff, M., 1975. The Delphi Method. Techniques and Applications, Mass.: Addison-Wesley Pub.

Marshall, J. N., Alderman, N., Wong, C. and Thwaites, A., 1995. The Impact of Management Training and Development on Small and Medium-sized Enterprises. International Small Business Journal, 13 (4), pp.73-90.

Mueller, F., 1996. Human resources as strategic assets: an evolutionary resource-based theory. Journal of Management Studies, 33(6), pp. 757-785.

Muñoz, R.M. and Salinero, M.Y., 2011. Training as a source of competitive advantage: performance impact and the role of firm strategy, the Spanish case. The International Journal of Human Resource Management, 22, pp. 574-594.

$\mathrm{Ng}$, I. and Dastmalchian, A., 2011. Perceived training benefits and training bundles: a Canadian study. The International Journal of Human Resource Management, 22, pp. 829-842.

Ng, Y.C. and Siu, N.Y.M., 2004. Training and enterprise performance in transition: evidence from China. The International Journal of Human Resource Management, 15, pp.878-894.

Nikandrou, I., Apospori, E., Panayotopoulou, L., Stavrou, E.T., and Papalexandris, N., 2008. Training and firm performance in Europe: The impact of national and organizational characteristics. International Journal of Human Resource Management, 19(11), pp. 2057-2078.

Peteraf, M.A., 1993. The cornerstones of competitive advantage: a resource-based view, Strategic Management Journal, 14, pp. 179-191.

Pickett, L., 1998. Competencies and managerial effectiveness: Putting competencies to work. Public Personnel Management, 27, pp. 103-115.

Rowe, G. and Wright, G., 1996. The impact of task characteristics on the performance of structured group forecasting techniques. International Journal of Forecasting, 12, pp. 73-89.

Russell, J.S., Terborg, J.R. and Powers, M.L., 1985. Organizational performance and organizational level training and support. Personnel Psychology, 38, pp. 849-863.

Schultz, T.W., 1961. Investment in human capital. American Economic Review, 51, pp. $1-17$.

Shapiro, C., Stiglitz, J., 1984. Equilibrium unemployment as a worker discipline device, American Economic Review, 74, pp. 433-444.

Schuler, R.S., 1987. Personnel and Human Resource Management Choices and Organizational Strategy. Human Resource Planning, 10 (1), pp. 1-17.

Schuler, R.S. and Jackson, S.E., 1987. Linking Competitive Strategies with Human Resource Management Practices. The Academy of Management Executive, 1 (3), pp. 207-219

Spence, M., 1973. Job Market Signalling. Quarterly Journal of Economics, 87, pp. 355-374.

Stiglitz, J.E. and Weiss, A., 1981. Credit rationing in markets with imperfect information. American Economic Review, 71(3), pp. 393-410.

Storey, D.J., 2004. Exploring the link, among small firms, between management training and firm performance: A comparis-ion between the UK and other OECD countries, International Journal of Human Resource Management, 15(1), pp. 112-130.

Tharenou, P., Saks, A.M. and Moore, C., 2007. A review and critique of research on training and organizational-level outcomes. Human Resource Management Review, 17, pp. 251-273. 
Úbeda, M., 2005. Training and business performance: the Spanish case, The International Journal of Human Resource Management, 16(9), pp. 1691-1710.

Van de Ven, A.H. and Delbeq, A. L., 1971. "Nominal versus Interacting group processes for comitte decision making effectiveness". Academy of Management Journal, 14, pp. 203-212.

Williamson, O., 1975. Markets and Hierarchies: Analysis and Antitrust Implications. Nueva York: The Free Press.

Waldman, M., 1984. Job Assignments, Signalling and Efficiency. RAND Journal of Economics, 15, pp. 255-267.

Waldman, M., 1990. "Up-or-Out Contracts: A signaling Perspective". Journal of Labor Economics, 8, pp. 230-250.

Williamson, O., 1975. Markets and hierarchies: Analysis and antitrust implications, New York: Free Press.

Williamson, O., 2005. Why Law, Economics and Organization?. Annual Review of Law and Social Sciences, 1, pp. 369-396.

Wright, P.M., McMahan, G.C. and McWilliams, A., 1994. Human resources and sustained competitive advantage: A resource-based perspective. The International Journal of Human Resource Management, 5, pp. 301-326. 
